\title{
Mesozoic-Cenozoic Stratigraphy and Tectonic Development of the Southern Great Tarakan Basin, Northeast Borneo, Indonesia
}

Rudarsko-geološko-naftni zbornik

(The Mining-Geology-Petroleum Engineering Bulletin) UDC: $551.1: 551.24: 550.93$

DOI: 10.17794/rgn.2022.1.11

Original scientific paper

\author{
Alfathony Krisnabudhi'; Benyamin Sapiie'; Agus Men Riyanto²; \\ Adi Gunawan'; Febriana Fiona Rizky ${ }^{1}$ \\ ${ }^{1}$ Bandung Institute of Technology (ITB), Bandung, 40116 Indonesia \\ ${ }^{2}$ National Research and Innovation Agency (BRIN), Bandung, 40135 Indonesia \\ ${ }^{3}$ Pertamina Hulu Energy, Jakarta, 12520 Indonesia
}

\begin{abstract}
We analyzed the tectonics and stratigraphy of the Southern Great Tarakan Basin to determine its tectonic evolution during the Mesozoic-Cenozoic eras, the evolution of basin geometry, and the potential of hydrocarbon using integrated surface and subsurface data. The Southern Great Tarakan Basin can be divided into three sub-basins, Berau, Muara, and South Tarakan. They comprise deposits of Jurassic to Quaternary age, which can be assigned five mega sequences based on their lithological characteristics and tectonic development. We divide the tectonic events into four main phases; (1) contractional Jurassic-Cretaceous, (2) extensional Paleogene, (3) subsidence Early Neogene, and (4) contractional Late Neogene. The development of the strike-slip activity influenced the geometric evolution of the two sub-basins. NW-SE transpressional structures formed during the contraction phase caused most of the existing structure in Paleogene reactivated and inverted, followed by basement uplift and erosion. Consequently, the evolution of the transpressional system caused the Great Tarakan Basin to be divided into five sub-basins during the Late Miocene-Pliocene. Moreover, five horizons with hydrocarbon potential exist in the southern part of the Greater Tarakan Basin; three plays in the Berau Subbasin, and two main plays in the Muara Sub-basin. The Late Neogene structures in the Berau Sub-basin control the accumulation, migration, and trapping mechanism, whereas these structures do not exist in Muara; hence, this sub-basin is dominated by stratigraphic traps.
\end{abstract}

Keywords:

Jurassic-Quaternary; stratigraphy; tectonics; hydrocarbon potential; NE Borneo

\section{Introduction}

The Greater Tarakan Basin is one of the basins situated along the eastern Kalimantan passive margin (see Figure 1) (Wight et al., 1993; Doust and Noble, 2008; Wijayanti et al., 2014; Koesoemadinata, 2020). The Great Tarakan Basin is divided into two parts. The Tarakan, Malinau, and Tidung sub-basins are located in the north, while the Berau and Muara sub-basins are situated in the southern area (see Figure 1) (Maulin et al., 2019). Geometry and bathymetry in the northern sub-basin zone are deeper to the Celebes Sea, indicating that sedimentation is moving deeper eastward (Tiranda and Hall, 2021). The analysis and interpretation of the residual anomaly gravity map (Wijayanti et al., 2014; Maulin et al., 2021) reveals two major depocentres, the $\mathrm{N}-\mathrm{S}$ and $\mathrm{W}-\mathrm{E}$ pattern in the west and east of the Berau depocentre. According to recent studies, the two depocentres are separated by the NW-SE trending structure

Corresponding author: Alfathony Krisnabudhi alfathonybudhi@gmail.com known as the North Mangkalihat Fault Zone (NMFZ) and the Latih Fault Zone (LFZ) (Krisnabudhi et al., 2020).

Stratigraphy and tectonic developments in the northern zone have been well documented, particularly during the Neogene period (Ahmad and Samuel, 1984; Hidayat et al., 1995; Lentini and Darman, 1996). Most of the outcrops in the northern sub-basin Tarakan and Tidung are dominated by Neogene-Quaternary deposits, while Mesozoic-Paleogene outcrops are limited. The presence of Neogene tectonically activated deltas indicates that the development of sedimentary and basins in the northern region is controlled by uplift followed by erosion and rapid sedimentation (Hidayati et al., 2007; Morley et al., 2017; Maulin et al., 2019). In the southern area lithological units of Mesozoic to Quaternary age can be found. The identification of Paleogene to Neogene sediments in the south, on the other hand, refers to the stratigraphy of the northern area. The southern zone has a high stratigraphic complexity in terms of lithology, age, and geological structure (Situmorang and Burhan, 1995; Krisnabudhi et al., 2020). 

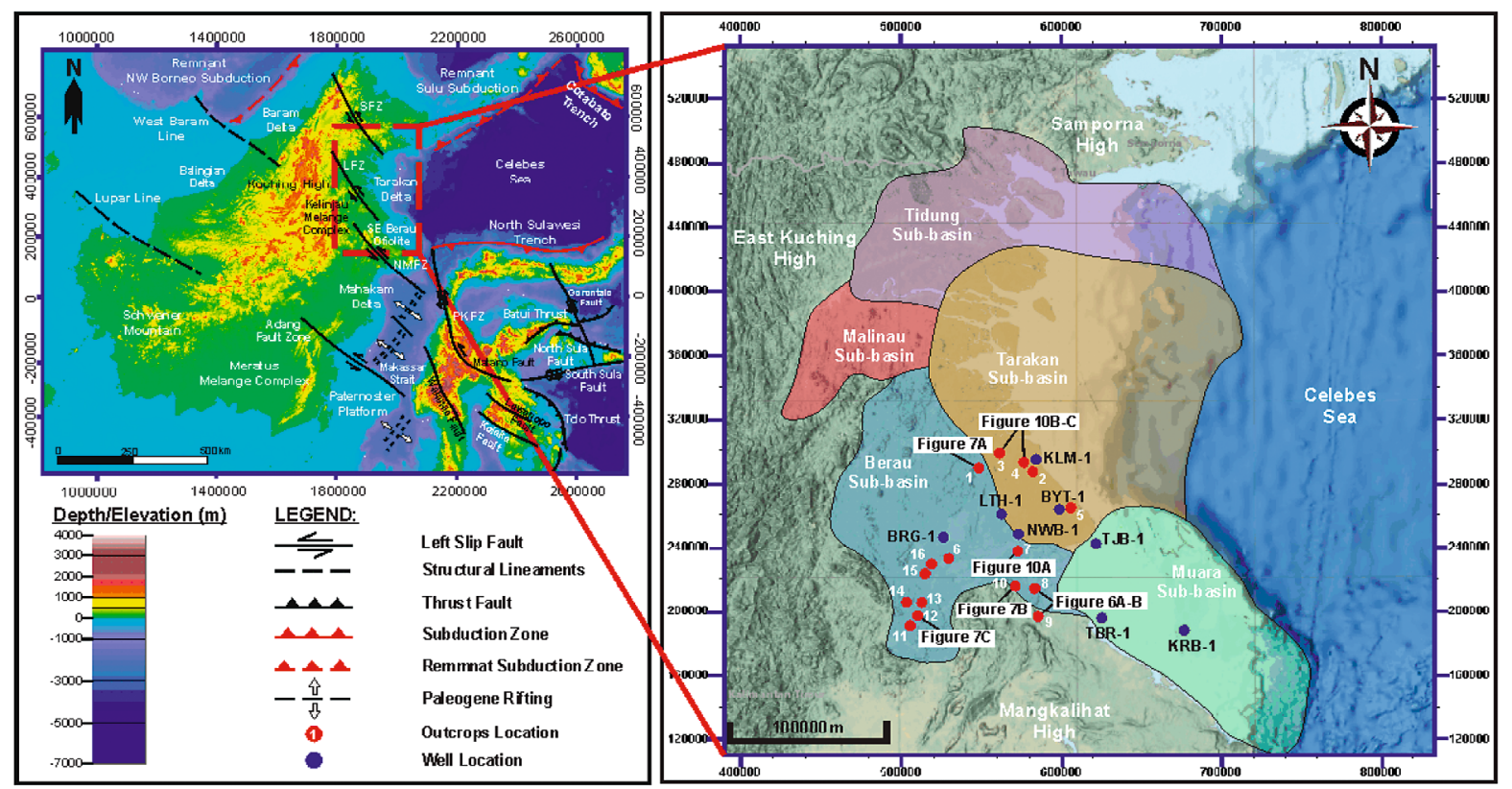

Figure 1: The left map shows the location of the research area and the tectonic and structural elements of Borneo and the surrounding region (from Satyana et al., 1999, modified). The right map shows the sub-basin division of northeast Borneo consisting of the Muara and Berau sub-basins in the southern part and the Malinau, Tarakan, and Tidung sub-basins in the northern side (from Lentini and Darman, 1996, modified), wells and outcrops location.

The appearance of metamorphic rock units in the northwest Berau Sub-basin area demonstrates the complexity of the lithological units in the southern part (Situmorang and Burhan, 1995; Supriatna and Abidin, 1995). The existence of these metamorphic rock units is also a point of contention when reconstructing tectonic developments in the Southern Great Tarakan Basin. According to studies conducted between the year 1990 and 2012, metamorphic rock units exposed in Mangkalihat are linked to the W-E Sambas-Mangkalihat subduction process during the Early Cretaceous period (Amiruddin, 2000; Amiruddin, 2009; Hartono, 2012). In contrast, Soesilo et al., (2015) state that the presence of metamorphic units is part of the Meratus-Mangkalihat paired metamorphic belt with a NE-SE pattern.

The purpose of this paper is to reveal and analyze the stratigraphy and tectonic developments in the Berau and Muara sub-basins during the Mesozoic to Cenozoic periods. We used surface and subsurface data in analysis and interpretation to answer the following research questions: (1) What is the nature of the tectonic evolution of the Southern Great Tarakan Basin? (2) How have tectonics influenced basin geometry and stratigraphy in the two sub-basins? (3) What are the consequences of tectonic development for the presence of hydrocarbons in the two sub-basins? We propose an updated crosssectional model of tectonic evolution as well as a tectonostratigraphic model in the two southern sub-basins. The entire model will also describe the implications of tectonic and stratigraphic development to the presence of hydrocarbon potential of the two sub-basins.

\section{Data and Methods}

\subsection{Data and Methodology}

This study is based on the combination of surface and subsurface data. Surface data were derived from lithological mapping in the southeast, southwest, and central Berau Sub-basin, as well as mapping in the southeast onshore Tarakan Sub-basin. The subsurface data provided by PT. Pertamina Hulu Energi Indonesia came from eight exploration wells, data core, cutting and sidewall core, and 296 2D seismic cross-sections spread across the Berau, Tarakan, and Muara sub-basins.

\subsubsection{Surface Data}

The surface data includes lithological units obtained by lithological mapping (see Table 1), the results of which are used to identify lithology units. Petrographic analysis is performed on selected samples to determine the types of rocks and minerals.

The samples were examined under an optical microscope at the Research Center for Geotechnology LIPI laboratory in Bandung, Indonesia. The results of petrographic analyses were used to support the tectonic framework development in northeast Borneo, particularly in the Berau, Muara, and Tarakan sub-basins.

\subsubsection{Subsurface Data Well, Cutting, and Core Data}

In this study, we analyzed eight exploration wells provided by PT. Pertamina Hulu Energi Indonesia. The data 
Table 1: Outcrops coordinate location and lithology type in the study area

\begin{tabular}{|l|l|l|l|}
\hline No & Lithology & Formation & Coordinates \\
\hline 1 & Shale & Sembakung & $2.602222 \mathrm{~N}, 117.500833 \mathrm{E}$ \\
\hline 2 & Clay with coal cleat & Sadjau & $2.625556 \mathrm{~N}, 117.748333 \mathrm{E}$ \\
\hline 3 & Quartz sandstone with coal and clay & Sadjau & $2.699444 \mathrm{~N}, 117.596389 \mathrm{E}$ \\
\hline 4 & Quartz sandstone with conglomerate & Sadjau & $2.655833 \mathrm{~N}, 117.700556 \mathrm{E}$ \\
\hline 5 & Quartz sandstone & Sadjau & $2.405389 \mathrm{~N}, 117.911994 \mathrm{E}$ \\
\hline 6 & Sandstone interbedded with siltstone and coal & Latih & $2.144894 \mathrm{~N}, 117.448703 \mathrm{E}$ \\
\hline 7 & Sandstone & Latih & $2.148935 \mathrm{~N}, 117.690253 \mathrm{E}$ \\
\hline 8 & Serpentinite & Ophiolite & $1.963511 \mathrm{~N}, 117.738779 \mathrm{E}$ \\
\hline 9 & Pillow lava (basalt) and chert & Ophiolite & $1.910653 \mathrm{~N}, 117.763897 \mathrm{E}$ \\
\hline 10 & Limestone & Birang & $1.988889 \mathrm{~N}, 117.695278 \mathrm{E}$ \\
\hline 11 & Metasandstone & Telen & $1.780000 \mathrm{~N}, 117.184722 \mathrm{E}$ \\
\hline 12 & Limestone & Birang & $1.796111 \mathrm{~N}, 117.218611 \mathrm{E}$ \\
\hline 13 & Limestone & Birang & $1.815000 \mathrm{~N}, 117.232222 \mathrm{E}$ \\
\hline 14 & Dominated sandstone with minor shale & Kelai & $1.839167 \mathrm{~N}, 117.115278 \mathrm{E}$ \\
\hline 15 & Sandstone with minor shale & Lebak & $2.071111 \mathrm{~N}, 117.354722 \mathrm{E}$ \\
\hline 16 & Conglomerate & Labanan & $2.081389 \mathrm{~N}, 117.384167 \mathrm{E}$ \\
\hline
\end{tabular}

Table 2: Research techniques applied to exploratory wells in the research area

\begin{tabular}{|l|l|l|l|l|l|l|l|l|}
\hline \multirow{2}{*}{ Remarks } & Wells & \multicolumn{9}{|l|}{} \\
\cline { 2 - 9 } & BRG-1 & BYT-1 & KLM-1 & LTH-1 & NWB-1 & TJB-1 & TBR-1 & KRB-1 \\
\hline Gamma ray & $\mathrm{x}$ & $\mathrm{x}$ & $\mathrm{x}$ & $\mathrm{x}$ & $\mathrm{x}$ & $\mathrm{x}$ & $\mathrm{x}$ & $\mathrm{x}$ \\
\hline Density & $\mathrm{x}$ & & $\mathrm{x}$ & $\mathrm{x}$ & $\mathrm{x}$ & $\mathrm{x}$ & $\mathrm{x}$ & \\
\hline Sonic & $\mathrm{x}$ & $\mathrm{x}$ & $\mathrm{x}$ & $\mathrm{x}$ & $\mathrm{x}$ & $\mathrm{x}$ & $\mathrm{x}$ & $\mathrm{x}$ \\
\hline Resistivity & $\mathrm{x}$ & & $\mathrm{x}$ & $\mathrm{x}$ & $\mathrm{x}$ & $\mathrm{x}$ & $\mathrm{x}$ & $\mathrm{x}$ \\
\hline Caliper & $\mathrm{x}$ & & $\mathrm{x}$ & $\mathrm{x}$ & $\mathrm{x}$ & $\mathrm{x}$ & $\mathrm{x}$ & $\mathrm{x}$ \\
\hline Neutron & $\mathrm{x}$ & & $\mathrm{x}$ & $\mathrm{x}$ & $\mathrm{x}$ & $\mathrm{x}$ & $\mathrm{x}$ & $\mathrm{x}$ \\
\hline Checkshot & $\mathrm{x}$ & $\mathrm{x}$ & $\mathrm{x}$ & $\mathrm{x}$ & $\mathrm{x}$ & $\mathrm{x}$ & $\mathrm{x}$ & $\mathrm{x}$ \\
\hline Composite $\log$ & $\mathrm{x}$ & $\mathrm{x}$ & $\mathrm{x}$ & $\mathrm{x}$ & $\mathrm{x}$ & $\mathrm{x}$ & $\mathrm{x}$ & $\mathrm{x}$ \\
\hline Tops & $\mathrm{x}$ & $\mathrm{x}$ & $\mathrm{x}$ & $\mathrm{x}$ & $\mathrm{x}$ & $\mathrm{x}$ & $\mathrm{x}$ & $\mathrm{x}$ \\
\hline Core & & $\mathrm{x}$ & & & & $\mathrm{x}$ & & $\mathrm{x}$ \\
\hline Cutting & $\mathrm{x}$ & $\mathrm{x}$ & $\mathrm{x}$ & $\mathrm{x}$ & $\mathrm{x}$ & $\mathrm{x}$ & & $\mathrm{x}$ \\
\hline Side wall core & & $\mathrm{x}$ & & & & $\mathrm{x}$ & & $\mathrm{x}$ \\
\hline
\end{tabular}

from these wells are well classified, and some data can be lithologically calibrated due to the presence of sample core data and cuttings (see Table 2). The eight wells were interpreted in order to determine the types of sediments, deposition environments, and stratigraphic sequences in the Berau, Muara, and Tarakan sub-basins. Each well has the reports of biostratigraphic data that are used to determine the age of a geological formation at each depth, then identify the sequence boundary using lithological changes derived from cutting information and triple-combo log patterns. Furthermore, the correlation of wells gave us insight into lateral changes in deposition. The interpretation yields ten intervals ranging from the basement to Quaternary sediments.

\subsubsection{Seismic Data}

Seismic analyses yielded vectorized 2D migration seismic data. Seismic trajectories include the Berau, Muara, and Tarakan sub-basins, with a total cross-section of 296 seismic lines. Seismic interpretation is carried out on Petrel E\&P software with a license from PT. Pertamina Hulu Energi Indonesia. It is based upon biostratigraphic marker controls from exploration well report data from the Berau, Muara, and Tarakan sub-basins. The average value of the well to the seismic tie between these seismic data and the eight exploration wells is $0.71-0.80$. The seismic stratigraphy method after Mitchum and Vail (1977) is used to determine the con- 
figuration of geological structures and lateral continuity from Mesozoic to Quaternary stratigraphy. The results of this seismic interpretation will be used to determine sedimentation control of geological structure development caused by plate tectonics and gravitational tectonic processes in the Berau, Muara, and Tarakan sub-basins.

\section{Results and Discussion}

\subsection{Tectonic Framework}

The Southern Great Tarakan Basin is a part of the southeast Sundaland, which is bounded by the Celebes Sea, the subduction zone of the north Sulawesi and the Palu Koro Fault Zone (PKFZ) in the northeast-eastern area, the Mangkalihat High and Samporna High in the south and north, and Central Borneo Range/Kuching High in the west (see Figure 1). Currently, the boundary between the continental basement and the oceanic basement of the North Sulawesi is interpreted to be in the western zone of the Celebes Sea (Cloke et al., 1999; Tiranda and Hall, 2021).

Geologically, the study area is influenced by three tectonic convergences and one tectonic divergence. The existence of these tectonic events serves as the basis for analyzing basin deformation and evolution. Hence, we divide the four major tectonic phases that emerged during the Mesozoic-Cenozoic period to simplify the tectonostratigraphic division in the Southern Great Tarakan Basin.

\subsubsection{Jurassic-Cretaceous Tectonic}

The presence of metamorphic outcrops in the Southern Great Tarakan Basin is the key to determine the Mesozoic tectonic. According to the geological map of the Muarawahau (Supriatna and Abidin, 1995), which is located to the west of the Berau Sub-basin, it shows a group of the Late Cretaceous mélange Kelinjau metamorphic unit with block fragments of the Devonian $\mathrm{He}$ liolites limestone and Early-Middle Jurassic ophiolite sequence in the southern side of the Berau Sub-basin.

According to the recent research, the metamorphic unit around the Mélange Kelinjau zone (West Berau Sub-basin) was formed 190 Ma ago (Early Jurassic) based on K-Ar dating (Soesilo et al., 2015). The presence of metamorphic units in Meratus (southeast Borneo) correlates with the age of the metamorphic unit lo-

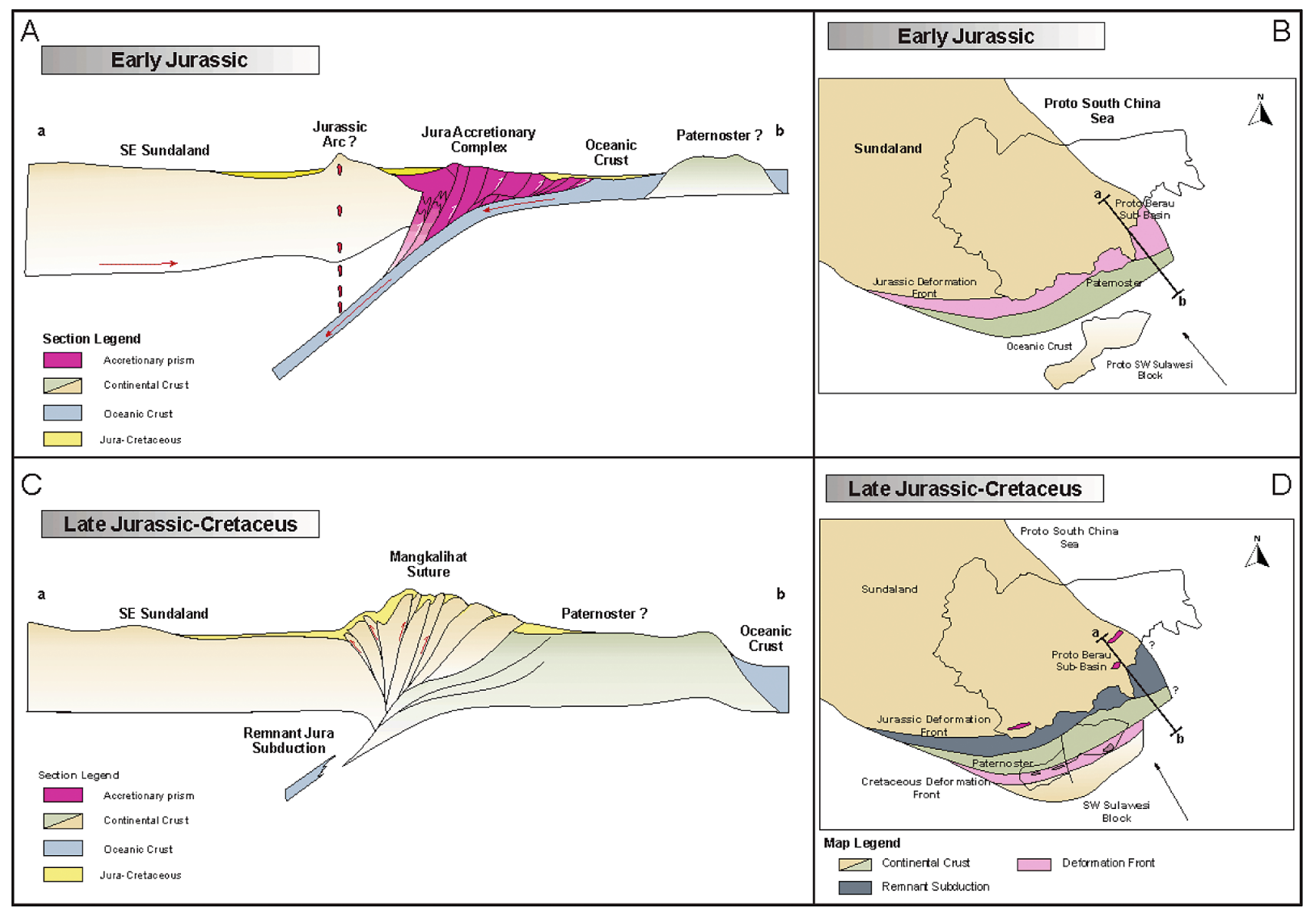

Figure 2: The tectonic cross-section and tectonic evolution of Borneo during Jurassic-Cretaceous (from Soesilo et al., 2015, modified). (A) Profile of the Early Jurassic subduction in SE Borneo; (B) paleogeography map of Early Jurassic in Borneo; (C) profile of the Late Jurassic to Cretaceous collision in along SE-NE Borneo; (D) paleogeography map of Late Jurassic to Cretaceous. 
cated in the west of the Berau Sub-basin (Mangkalihat). Hence, Meratus-Mangkalihat is interpreted as a paired metamorphic belt and classified as a Jurassic-Cretaceous suture (Soesilo et al., 2015).

The presence of the Kelinjau mélange unit, which consists of high pressure-low temperature (HPLT) and incomplete ophiolite sequence, indicates that in the Jurassic-Cretaceous, subduction-collision phase developed in the Southern Great Tarakan Basin. Subduction was caused by the movement of the oceanic crust relative to the north-northwest (Soesilo et al., 2015) in the Early Jurassic Epoch, which developed into a collision between Partenoster and southeast Sundaland in the Late Jurassic-Early Cretaceous Epoch. We interpreted that the Late Jurassic-Early Cretaceous collision resulted NE-SW Mangkalihat suture which extend from the Meratus, Kutai and North Mangkalihat area (see Figure 2).

\subsubsection{Paleogene Tectonic}

Tectonic developments greatly influenced the geometric evolution of the Berau and Muara sub-basins dur- ing the Paleogene. Around the two basins, two tectonic events occur; the northwest Borneo convergence (Tjia and Ismail, 1994; Hutchison et al., 2000; Hall, 2002; Balaguru and Nichols, 2004; Balaguru and Hall, 2009; Tjia, 2012; Pubellier and Morley, 2014; Hall and Breitfeld, 2017) and the Makassar Strait divergence (Cloke at al., 1999; Wilson and Moss, 1999; Guntoro, 1999; Nur'aini et al., 2005; Kupecz et al., 2013; Koesoemadinata, 2020) (see Figure 3).

According to the W-E trending seismic section in the Muara Sub-basin, the normal fault group has a significant influence on basin geometry and controls the thickness of the Eocene sediments (see Figure 4). The series of normal fault systems have a relatively N-S and NESW trending pattern that constantly form a basin geometry elongated in the direction of the fault pattern. This fault pattern resembles normal faults that are formed in Makassar Strait in terms of genesis and age.

The presence of these normal faults is a result of the Makassar Strait rifting process that occurred between the Paleocene and Late Eocene period (Nur'aini et al.,

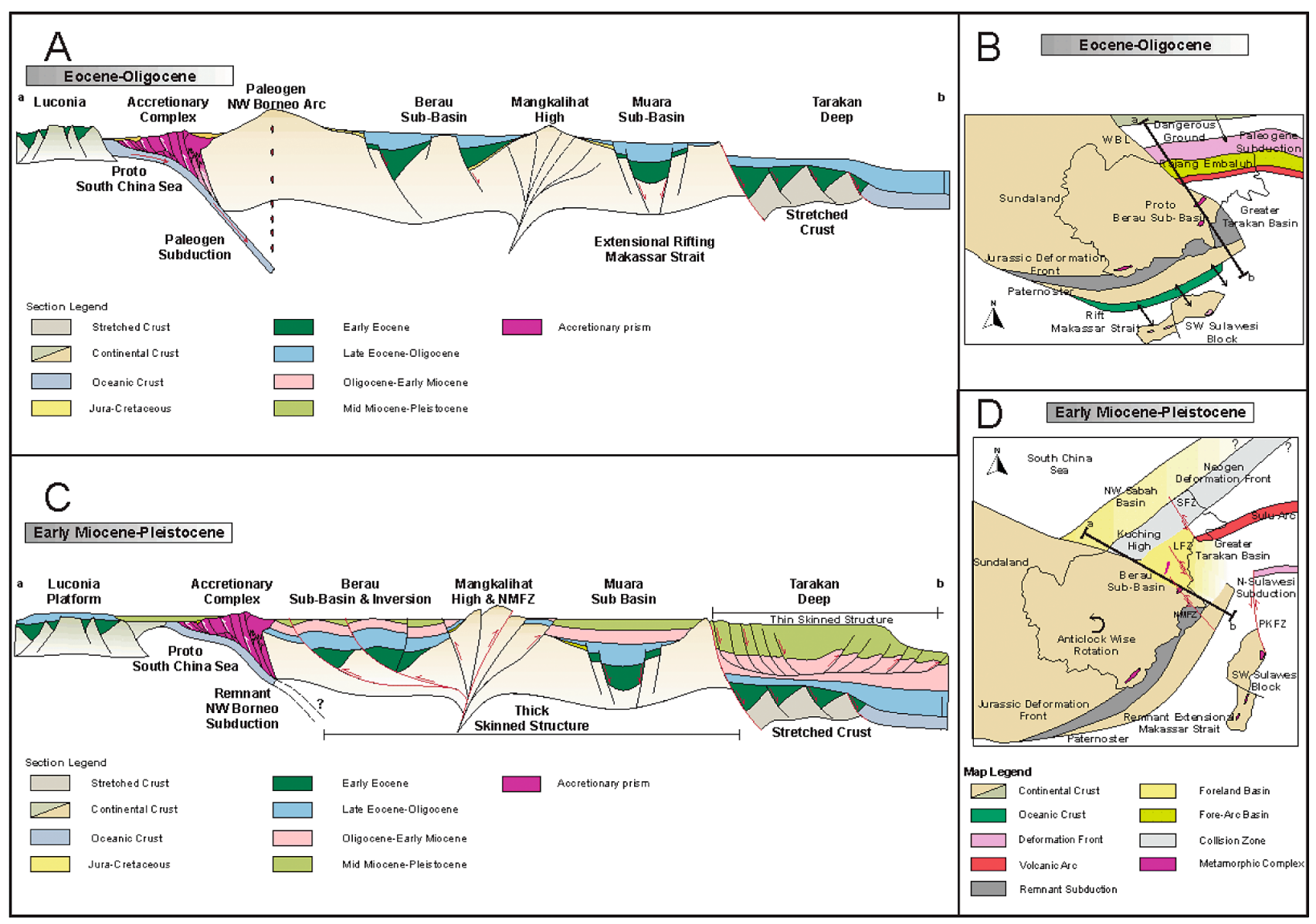

Figure 3: The tectonic evolution of Borneo during the Eocene-Pleistocene (from Hidayati et al., 20o7, modified). (A) Profile of the Eocene-Oligocene, two different tectonics occurred in the Paleogene, Makassar Strait rifting in the SE Borneo and subduction of the PSCS with NW Borneo; (B) paleogeography map of Eocene-Oligocene in Borneo; (C) profile of the Early Miocene-Pleistocene, Late Jurassic to Cretaceous, NW Borneo subduction had ceased in Early Miocene and was followed by the collision of NW Borneo with Luconia. In the Late Neogene-Quaternary, the NE Borneo region underwent a process of developing the transpressional system and inversion structure; (D) paleogeography map of Early Miocene-Pleistocene. 
2005; Pubellier and Morley, 2014). In general, rifting in the Makassar Strait affects not only the development of the Southern Great Tarakan Basin but also the geometric evolution of the Kutai Basin (East Borneo), the Barito Basin (Southwest Borneo), and the N-S Makassar Basin (Satyana et al., 1999; Nur'aini et al., 2005; Bachtiar et al., 2013 and Kupecz et al., 2013).

The extensional rifting process in Southern Great Tarakan is divided into three stages: (1) the extensional initiation stage, which occurred during the Late Paleocene-Early Eocene, the N-S normal faults series began to form depocentres in the Berau and Muara Sub-basin zones during this period, (2) extensional climax which began in the Middle-Late Eocene period. During this time the sediments accumulated in the border fault as a consequence of graben and half-graben development with a N-S pattern (see Figure 4 and Figure 5), (3) the final development stage of the N-S trending normal fault system during the Oligocene period. In this stage, the $\mathrm{N}-\mathrm{S}$ normal fault system has ceased. The sedimentation processes dominated by the development of carbonate in the basement high and clastic sediment deposited with a thermal subsidence mechanism.

On the northern side of Borneo, subduction between the Proto South China Sea (PSCS) ocean plate and northwest Borneo occurred, and this subduction continued throughout the Eocene-Early Miocene period (Hall, 2013; Hall and Breitfeld, 2017). We believe that the subduction was followed by the development of a volcanic arc, the products of which, such as volcanic tuff, were well deposited and recorded in the Berau and Muara sub-basins. According to this evidence, the geometry development is influenced more by the Makassar Strait rifting process than by the PSCS - Northwest Borneo subduction process.

\subsubsection{Early-Middle Neogene Tectonic}

The Neogene tectonic development is divided into two sub-events, a transition from the Paleogene Makassar Strait rifting in southeast Borneo and the next phase of subduction into a collision in northwest Borneo (Hall, 2013). The expansion of the syneclises generally determines the continuation phase of the rifting (Chamov et al., 2019).

As Paleogene's structural control began to disappear, the Southern Great Tarakan Basin experienced slow and steady subsidence in the Early Neogene period. The subsidence control results in the expansion of the syneclise, in which the sediment deposited at the time had a relatively thick layer with a slight slope angle along with the continental platform, in this case, the Muara Sub-basin (see Figure 4).

At the same time, Borneo experienced an anticlockwise rotation and the initiation of a collision in northwest Borneo. This anticlockwise rotation is interpreted as a regional tectonic manifestation of Gondwana's
(Australian Segment) N-NE movement (Wilson and Moss, 1999; Hall, 2002; Hall, 2012; Hall, 2013). Regionally, the anticlockwise rotation affects not only Borneo but the entire Southeast Asia region.

The collision caused the Kuching High to uplift on the west side of the study area. These events have had a significant impact on geological developments in the western and eastern parts of Kuching High. The existence of the Kuching High is interpreted as a result of the presence of Neogene sediments in the study area. Hidayati et al. (2007) interpreted the sedimentation rate during the Early - Middle Miocene in the west of the Great Tarakan Basin to be $60-121.92 \mathrm{~m} / \mathrm{My}$ increase to 91.44-228.6 m/My during the Late Miocene in the Tarakan deep offshore zone. We believe that the rapid sedimentation is related to the sub-development of collision and uplift in the western part of Borneo. When the climax collision phase occurred in the Late Neogene period, the Kuching High lift reached its maximum, and the Berau, Tarakan and Muara sub-basins experienced regional regression. These factors correlate with the development of thin-skinned structures offshore of Tarakan Deep.

The presence of thin-skinned structures is well recorded in the east area of Tarakan Deep. The W-E seismic section (see Figure 5) reveals that thick-skinned structures dominate the Berau, Muara Sub-basin, and onshore Southern Tarakan. In contrast, offshore Tarakan is dominated by normal listric fault structure packages that transform into toe thrust gliding due to gravitational force in the eastern part of Tarakan Deep. The two types of structures are generally separated by the Maratua-Derawan horst, which extends along the boundary of the continental crust and the oceanic crust of northeast Borneo.

\subsubsection{Late Neogene-Quaternary Tectonic}

The contractional effect is interpreted to dominate the development of the Southern Great Tarakan Basin zone during the Late Miocene-Pliocene period. The effect is caused by the existence of two structural systems that are identified as N-S inversion and NW-SE strike-slip system. These two structures are regionally the main factor in the geometry and basement configuration of the sub-basin group in the Southern Great Tarakan Basin.

This inversion structure zone (see Figure 5) is the boundary between the Kuching High on the east and the western Berau Sub-basin on the west. The existence of an inversion structure is caused by reactivation of the existing Paleogene structure, and the inversion causes Neogene sediments to experience uplift followed by erosion. There are two main strike-slip systems defined as the North Mangkalihat Fault Zone (NMFZ) and Latih Fault Zone (LFZ) (Krisnabudhi et al., 2020). The NMFZ extends from Sangkulirang Bay to the western part of the Berau Sub-basin, while the LFZ extends from the Berau delta to the northern part of the Tarakan Subbasin. Kinematically, the two strike-slips are categorized 

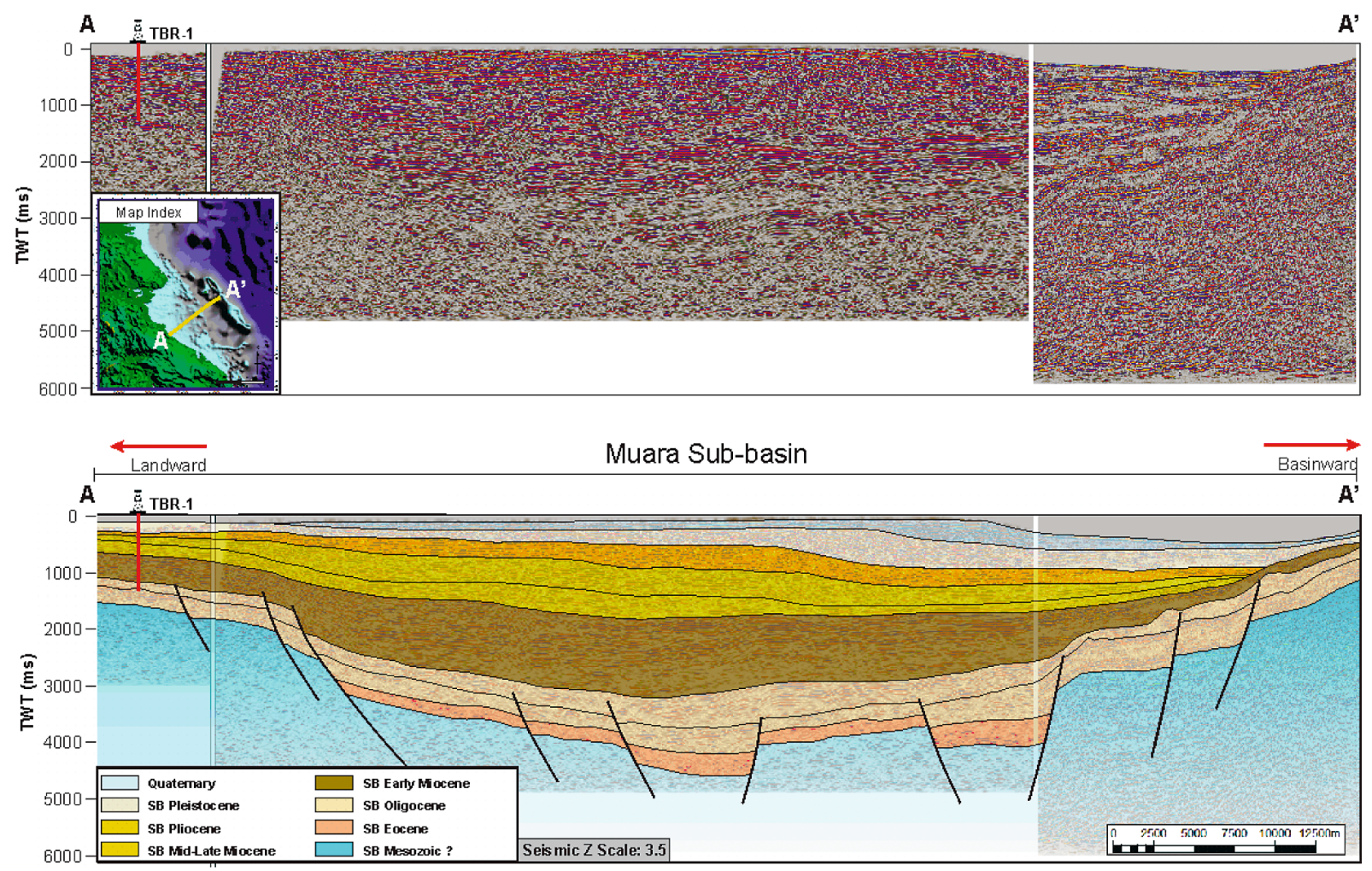

Figure 4: Interpretation of the west-east seismic section of the Muara Sub-basin region

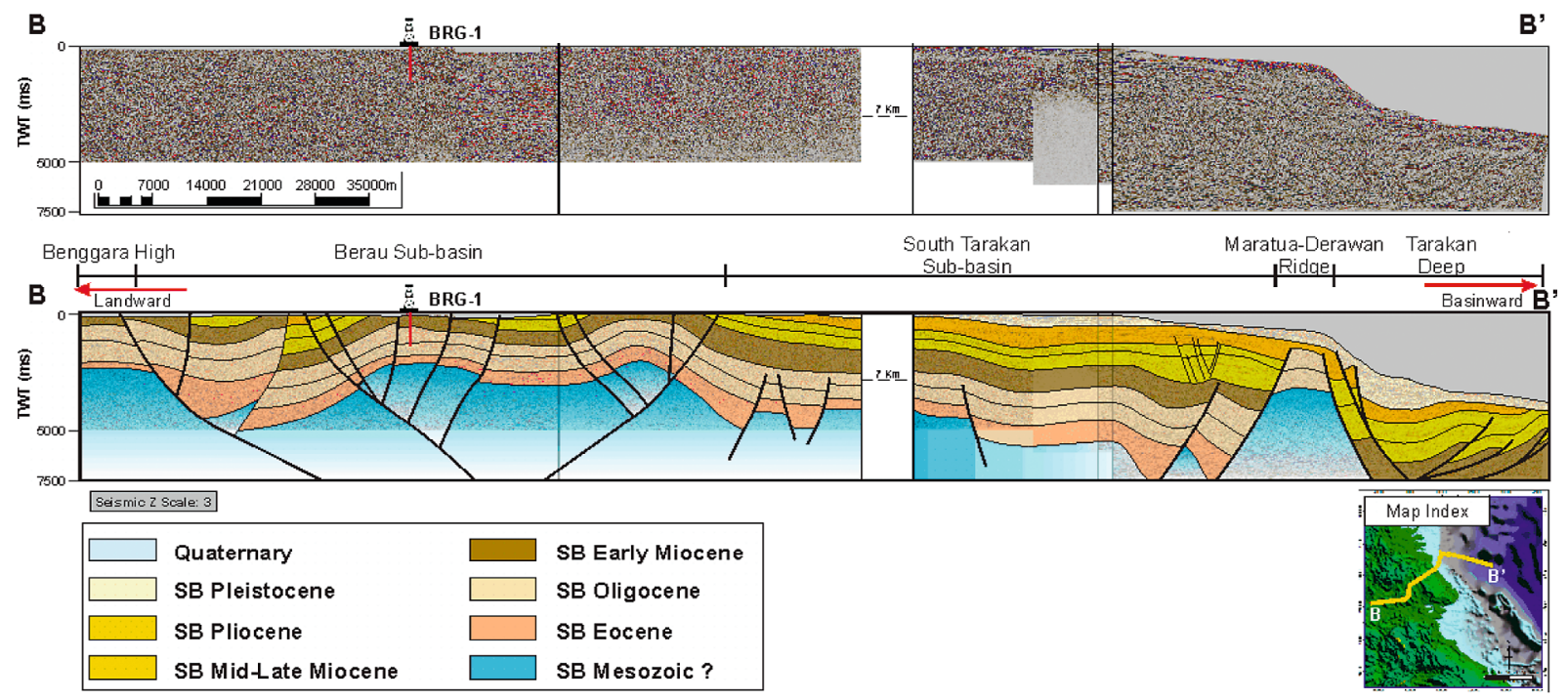

Figure 5: Interpretation of the west-east seismic section of the Berau Sub-basin to Tarakan Deep region. The West-Central Berau Sub-basin is mainly affected by flower and inversion structure, while in the Tarakan Deep region, it is controlled by a growth-toe thrust fault (thin-skinned structure).

as left slip faults. The interaction of the LFZ and NMFZ formed a transpressional system, and this causes the formation of N-S thrust and anticlinal system. Hence, in the west to central Berau Sub-basin experiences a large shortening. Therefore, the Paleogene-late Neogene deposits in the transpressional zone, experienced uplift and erosion. Meanwhile, in the NMFZ zone, the shortening caused the uplift of Mesozoic metamorphic and ophiolites groups. Based on tectonic analysis, we conclude that the development of the strike-slip system caused the division of the Southern Great Tarakan Basin into several sub-basins.

\subsection{Stratigraphic Development}

We divided the stratigraphy of the Southern Great Tarakan Basin into five megasequences; (1) the JurassicEarly Cretaceous, (2) the Late Cretaceous, (3) the Eo- 
cene, (4) the Oligocene-Early Miocene, and (5) the Middle Miocene-Pliocene sequence. The division is based on a major unconformity caused by significant changes of tectonic phases during the Jurassic-Cenozoic period. Stratigraphic development was identified based on outcrops and the interpretation of the data from eight exploration wells located in the Berau, Muara, and Southern Tarakan sub-basins.

\subsubsection{Jurassic - Early Cretaceous Sequence}

Based on the tectonic development mentioned in chapter 3.1.1, the Jurassic sequence is interpreted to have formed through the mechanism of subduction during the Early Jurassic Epoch. The HPLT metamorphic unit generally consists of blueschist, greenschist, and phyllite, and they are exposed in NEN-SWS in the Berau-Malinau Sub-basin (Supriatna and Abidin, 1995). In addition to the metamorphic HPLT unit, we discovered lithology units associated with the oceanic crust, such as pillow lava and serpentinite (see Figure 6). Situmorang and Burhan, (1995) and Supriatna and
Abidin, (1995) categorized the oceanic crust as the Jurassic Telen Formation. However, this classification is still a problem because of the lack of fossil and other stratigraphic dating information. Lithological variations of serpentinite, pillow lava, chert, and deep-marine sediments such as mudstone (see Figure 6) are categorized as incomplete ophiolite sequences, which are well exposed in the southeastern part of the Berau Sub-basin. The existence of radiolarian fossil Holocryptocanium $\mathrm{sp}$. indicates that the deep-marine sediments were deposited during the Middle Jurassic-Early Cretaceous (Krisnabudhi et al., 2020). In southwest Borneo, the presence of chert and radiolaria in the Meratus Mountains also has a Middle Jurassic-Early Cretaceous age (Wakita, 2000). Based on these two similarities, we define that the formation of the Meratus-southeast Berau ophiolite sequence has the same genesis.

\subsubsection{Late Cretaceous Sequence}

During the Late Cretaceous Epoch, unconformable regressive sediments were deposited above the meta-

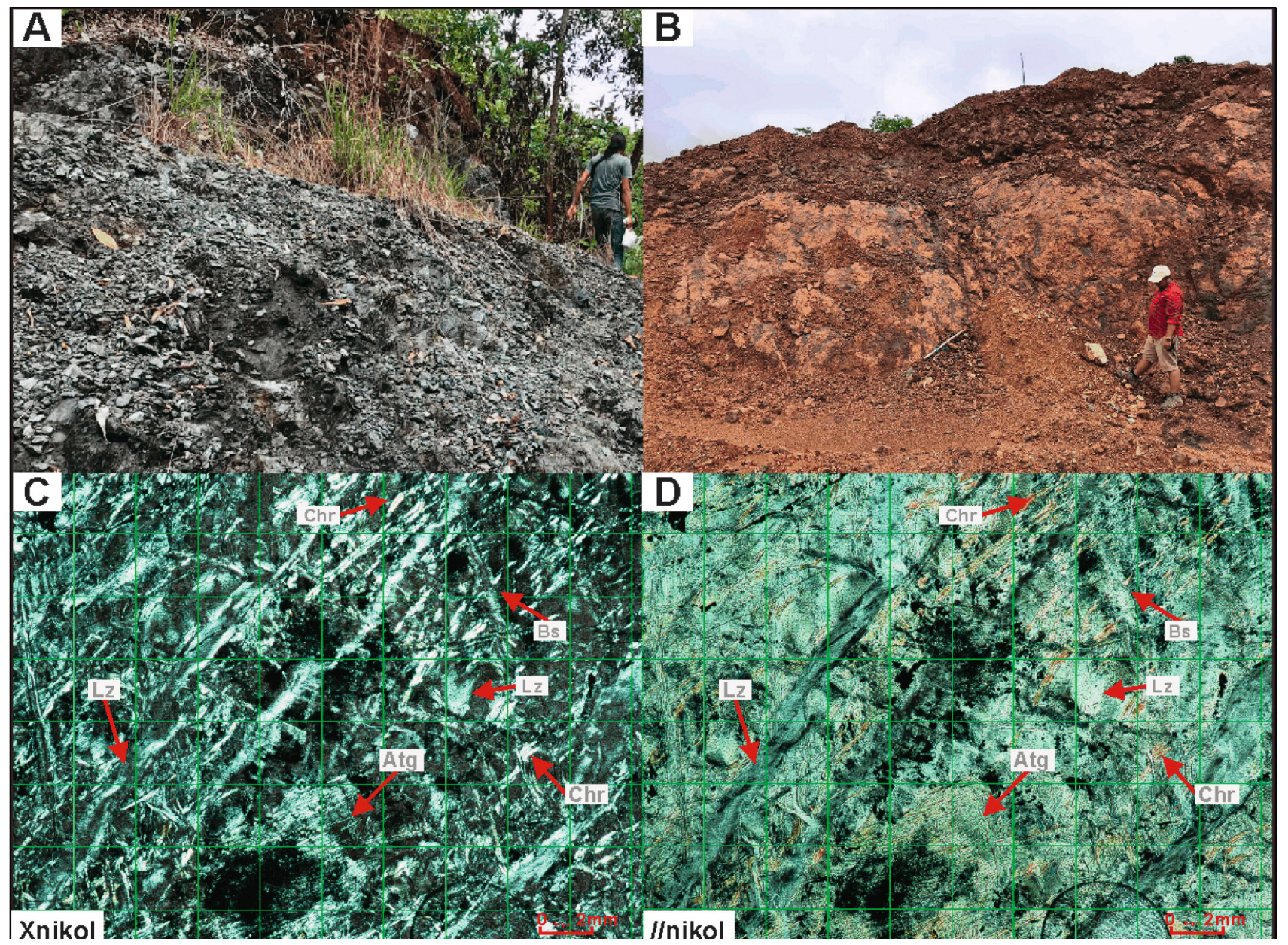

Figure 6: Mesozoic outcrops consisting of uncompleted ophiolite sequence of the southeastern Berau Sub-basin: (A) serpentinite metamorphic units (number 8 in Figure 1); (B) pillow lava units which are oceanic crust deposits (number 9 in Figure 1); (C \& D) petrographic analyses of metamorphic samples (number 8 in Figure 1) revealed serpentinite rocks with mineral compositions of $30 \%$ lizardite (Lz), 10\% basite (Bs), 30\% antigorite (Atg), and 30\% chrysotile (Chr). 
morphic unit and incomplete ophiolite sequence. The regressive deposits changed gradually to transgressive sediments during the Late Cretaceous. The regression process cannot be separated from the post-collision tectonic event in the Late Jurassic-Early Cretaceous. The high sediment supply caused by uplift and erosion is the main factor in filling the Southern Great Tarakan zone basin. Based on this, it is concluded that the Late Cretaceous deposits are categorized as syn-orogenic sediments.

Jamal et al. (1995) classified the Late Cretaceous deposits into two formations (Fm): Kelay Fm and Benggara Fm. The Kelay Fm is divided into three parts: the lower, middle and top. The lower part of Kelay Fm consists of terrestrial sediments such as conglomerates, polymictic breccias, quartz sandstones, and metasandstones. Shallow marine sediments such as calcareous sandstone, siltstone and limestone with intercalation claystone formed the middle part of this formation, while the top layers consist of deep-marine sediment groups such as dark claystone and chert. It can be deduced that this formation gradually changes from a regressive to a transgressive environment. The Benggara Fm consists of deep-marine sediments with lithological units similar to the upper Kelay Fm. As a result, we be- lieve the two formations had an interfingering relationship during the Late Cretaceous transgressive phase.

\subsubsection{Eocene Sequence}

Regionally, there was a hiatus during the PaleoceneEarly Eocene. This event is interpreted to be related to the regional unconformity in southeast Sundaland (Hall, 2012). Field observations, interpretation of data from eight wells and a comparative study based on the Tanjung Redeb geological map revealed that the sedimentation in the Southern Great Tarakan Basin was dominated by deep-marine deposits.

Figure 7A shows a shale unit, which is well exposed in the north of the Berau Sub-basin. Deposition of this unit is considered to have begun during the Middle Eocene. In general, it was deposited unconformably with respect to the Late Cretaceous Sequence. In addition to shale, Late Eocene tuff and tuffaceous claystone units were discovered. The presence of tuff units is closely related to Paleogene volcanic activity caused by subduction in northwest Borneo. The two lithologies have the same characteristics as the Sembakung Fm and Sajau Fm which deposited in the Berau, Muara, and Tarakan sub-basins.

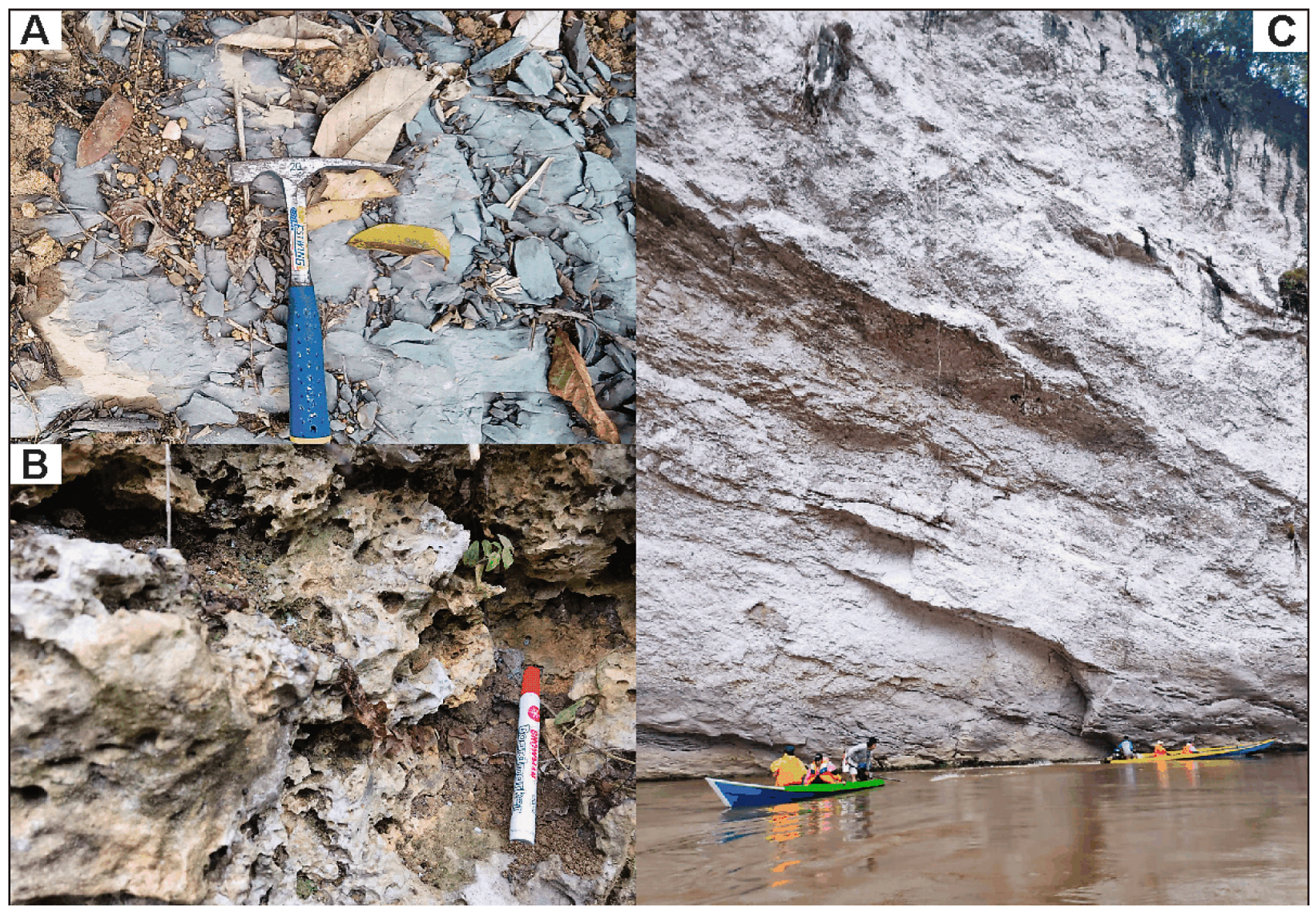

Figure 7: Paleogene outcrop: (A) Eocene shale (Sembakung Fm; number 1 in Figure 1); (B) Oligocene limestone (Seilor Fm; number 10 in Figure 1), (C) Late Oligocene-Early Miocene bioclastic limestones (Mangkubua Fm; number 12 in Figure 1). 
Based on the flattening of eight wells in the study area, the initial depositional analysis revealed that the Eocene sequence accumulated in the west of the Berau Sub-basin (see Figure 8) and the central part of the Muara Sub-basin (see Figure 9). The accumulation occurs specifically in the graben and half-graben bounded by the N-S pattern normal fault formed in the Paleogene period. Hence, we classify the Eocene Sequence as a syn-extensional deposit.

\subsubsection{Oligocene-Early Miocene Sequence}

During the Oligocene carbonate facies and claystone dominated the entire Muara Sub-basin of the Southern Great Tarakan Basin. This limestone unit was deposited unconformably over the Eocene sequence. In some places, limestone develops very well in horst structure that grows unconformably above the basement (see Figure 4). Wilson et al. (1999) proposed that the carbonates which developed in the upper Late Eocene-Early Oligocene were made up of mixed siliciclastic-carbonate shelves that predominated in the southeast Mangkalihat Peninsula. The upper Late Eocene-Early Oligocene car- bonate contains siliciclastic fragments of volcanic breccia, tuff and sandy limestones. The presence of these fragments indicates that carbonate development is not significant in the upper Eocene Sequence. This causes clastic material inputs to affect the development of the carbonate facies in the west and the depocentre grabenhalf graben zone in the central Muara Sub-basin. The appearance of horst in the Early Oligocene in the northwest and central Muara Sub-basin has become a medium for developing carbonate platforms (see Figure 4). These platforms are also interpreted as clastic carbonate sources during the erosion process, with the re-sedimentation sediments deposited in the depocentre zone formed around it. The lithology gradually changed to sandy limestone with calcareous claystone intercalation in the centre of the Muara Sub-basin (see Figure 5), implying that the sediment formed deeper in the sub-basin is the result of re-sedimentation from several carbonate platform systems in the Muara Sub-basin.

The stratigraphy deposited in the Early Oligocene is dominated by clastic limestone in the Berau Sub-basin (see Figure 7B). The clastic limestone group is interpreted to have formed due to the weathering, erosion and

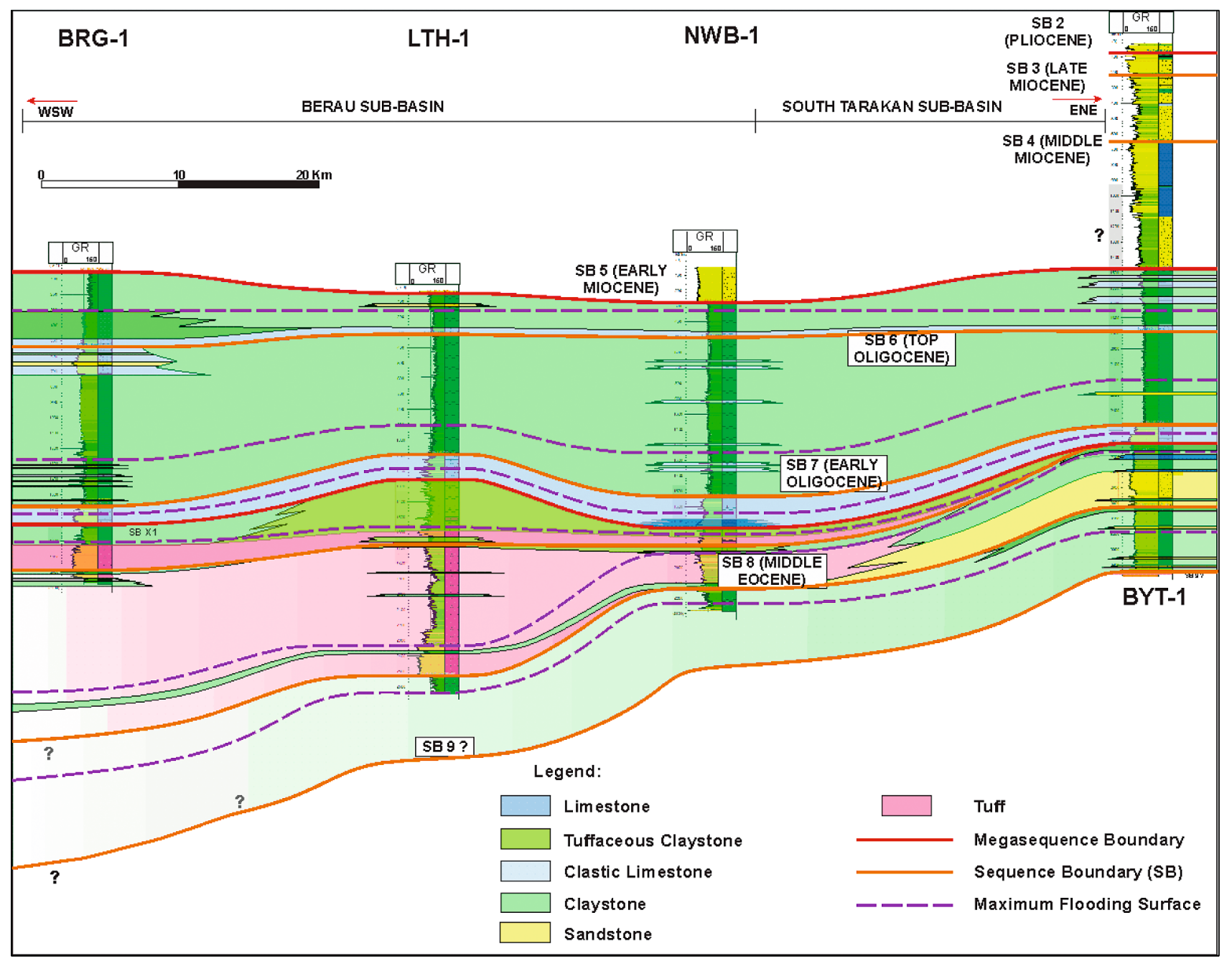

Figure 8: Stratigraphic correlation of the W-E Berau Sub-basin. 
re-sedimentation of a carbonate platform that grew in a horst within such a basin. Meanwhile, during the lower Late Oligocene, the stratigraphy was dominated by claystone units and clastic limestones deposited in a shelfbathyal environment (see Figures 7C and 8). The presence of this stratigraphic package was primarily due to sea-level rise and basin subsidence. In the upper Late Oligocene-Early Miocene, the presence of lower Late Oligocene claystone units gradually changed to interbedded claystone, sandy limestone with intercalation sandstone in Early Miocene. The change in lithological units indicates a drop in sea level corresponding with the start of collision and uplift in northwest Borneo. Hence, we conclude that the Early Oligocene sediment belongs to Seilor Fm, while the Late Oligocene sediment belongs to Mangkubua Fm. The carbonate platform Muara Subbasin formed in the Early Miocene belongs to Taballar
Fm, while clastic sediments in the Berau Sub-basin belong to Birang Fm and Tempillar Fm.

The depositional geometry analysis of the OligoceneEarly Miocene Sequence using wells and 2D seismic revealed that these sequences had relatively equal and balanced layer thicknesses (see Figures 4, 8, and 9), so we classified these sequences as post extensional deposits.

\subsubsection{Middle Miocene-Pliocene Sequence}

The presence of the Kuching High uplift in the Southern Great Tarakan Basin is a marker of regional regression during the Middle Miocene period. During this time, rapid sedimentation had formed deltaic facies that spread across the Southern Great Tarakan Basin.

Figure 10A illustrates the Middle Miocene stratigraphic unit composed of interbedded quartz sandstone,

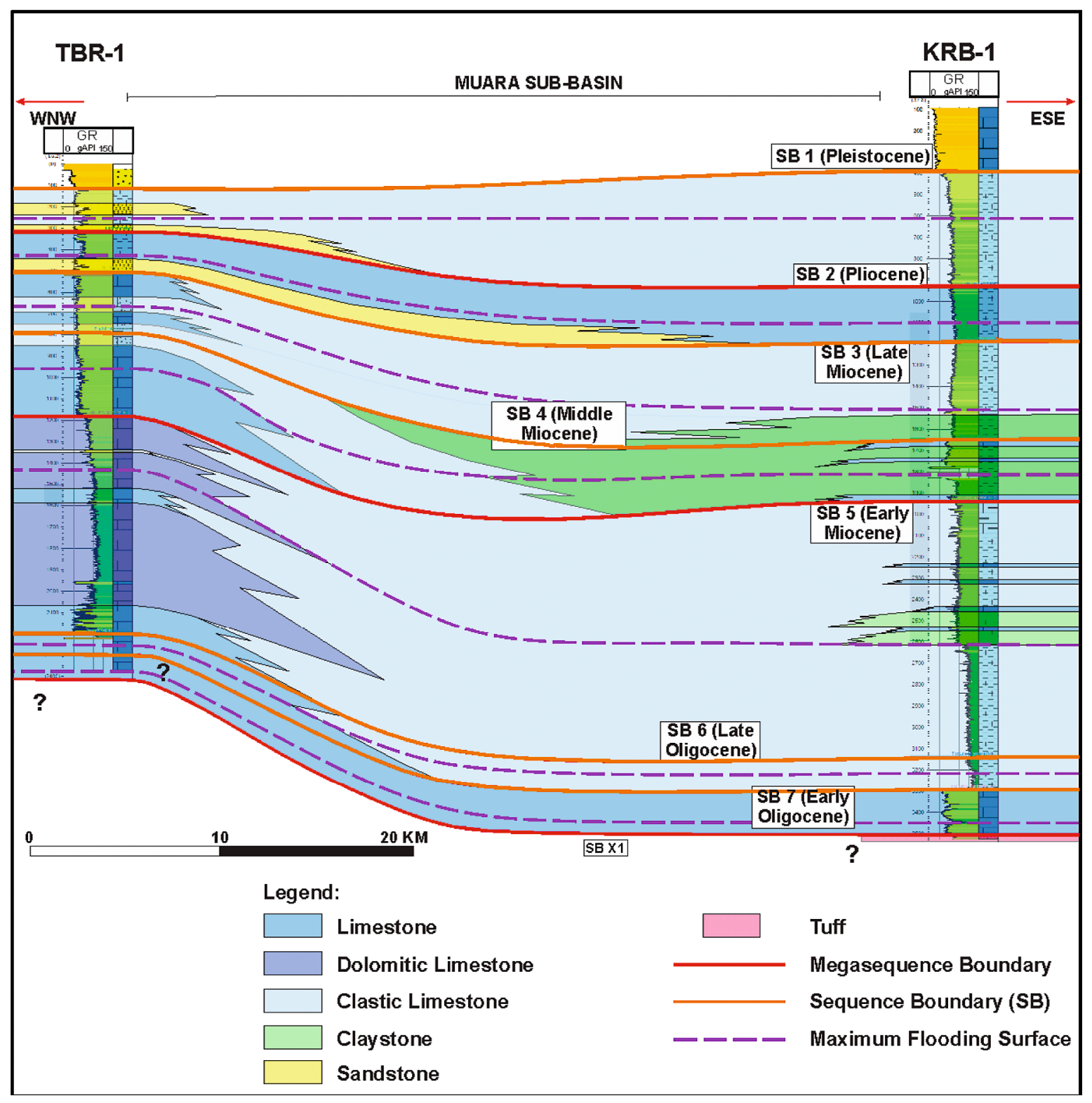

Figure 9: Stratigraphic correlation of the W-E Muara Sub-basin. 


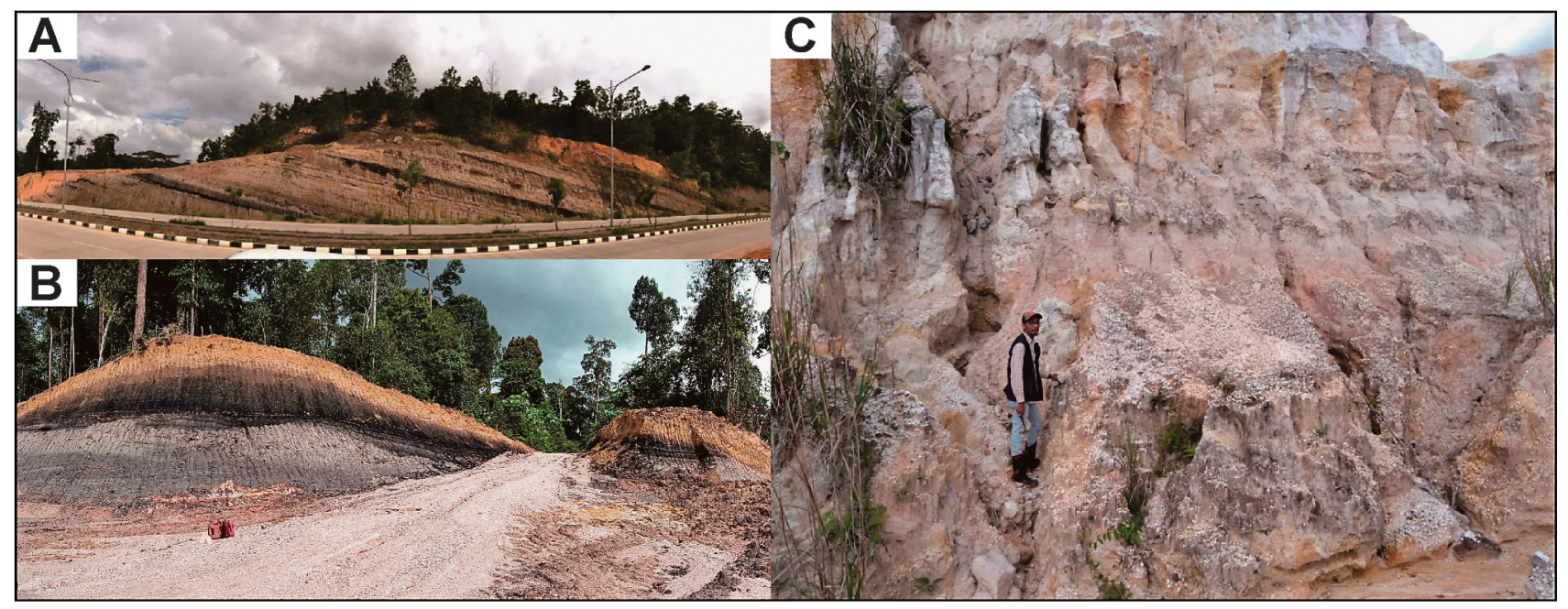

Figure 10: Neogene outcrops. (A) Interbedded quartz sandstone, claystone, and coal units of the Middle Miocene (Latih Fm; number 7 in Figure 1); (B) interbedded claystone, siltstone, and coal units of Early Miocene (Menumbar Fm; number 3 in Figure 1); (C) Pliocene units which consist of quartz sandstone and conglomerate

(Sajau Fm; number 4 in Figure 1).

claystone, and coal, and is well exposed in the central Berau Sub-basin. This unit is classified as Latih Fm based on age comparability and lithological characteristics (Situmorang and Burhan, 1995). The provenance of this formation comes from a recycled orogenic environment (Maryanto, 2012), which is interpreted as originating from Kuching High (Wijayanti et al., 2014). Berau's deltaic facies gradually transitioned to the shallow marine Muara Sub-basin. Menumbar Fm is the name given to the deposited shallow marine sediments, which consist of sandy limestones and calcareous claystone. Based on the evidence of the sequence stratigraphy analysis from well data, the sea-level rise was dominant during the Middle Miocene deposition.

The rapid sedimentation during the Pliocene had resulted in the development of fluvial, deltaic and shallow marine facies. In this period, two stratigraphic horizons can be observed; (1) the lower horizon composed of interbedded claystone, coal and quartz sandstone (see Figure 10B) and (2) the middle horizon composed of conglomerate and quartz sandstone interpreted as fluvialdelta deposits (see Figure 10C). The stratigraphic unit deposited during this period is Sajau Fm (Situmorang and Burhan, 1995; Wijayanti et al., 2014). It can be found locally in the western part of the Berau Sub-basin and the modern Berau Delta. This formation, unlike the Muara Sub-basin, was deposited evenly in a shallow marine environment. The mechanism of shortening was caused by the inversion and transpressional structure during the Late Miocene-Pleistocene. As a result of inversion and transpressional structure emergence in the Late Miocene - Pleistocene phase, these structures causing Sajau Fm deposition were localized in the Berau Sub-basin, particularly in the west and east areas. As a result, this phase becomes a significant factor Sajau Fm deposited in the Berau Sub-basin.
Based on the overall tectonic and stratigraphic events that occur in the Southern Great Tarakan Basin, we divided it into six stratigraphic tectonic phases, namely (1) Jurassic subduction and contractional which consist of the Basement and the Telen Formation; (2) Cretaceous collision and contractional which consist of the Benggara and Kelay formations; (3) Mangkalihat uplift in the Paleocene period and no deposition due to this tectonic event; (4) Eocene extensional phase which caused Makassar Strait rifting and deposition of the Sembakung Formation, Maliu Mudstone, and the Sujau Formation; (5) sagging phase and deposition of the Seilor and Mangkubua formations; (5) Early-Middle Neogene post extensional transitional phase and depositional of Taballar, Tempilar, Naintupo, Birang, Latih, and Tabul formations; (6) contractional and thin-skinned tectonic phases in the Late Neogene-Quaternary period with deposition of the Meliat, Menumbar, Santul, Sajau, Tarakan, Domaring, Waru, and Bunyu formations (see Figure 11).

\section{Implications for Hydrocarbon Potential}

In addition to their complex tectonic and stratigraphic histories, the Muara and Berau sub-basins have a high hydrocarbon potential (Wilson and Evans, 2002; Doust and Noble, 2008; Krisnabudhi et al., 2020), which is supported by a large amount of oil seepage in the Berau Sub-basin (Wight et al., 1993), which tends to point north (Situmorang, and Burhan, 1995). The accumulation of oil seepage around the contractional structure indicates that the petroleum system has performed admirably (Macgregor, 1992).

The Eocene sequence, which includes syn-extension sediments, is interpreted as a strong candidate for Paleogene source rock. Paleogene reservoirs are Oligocene 


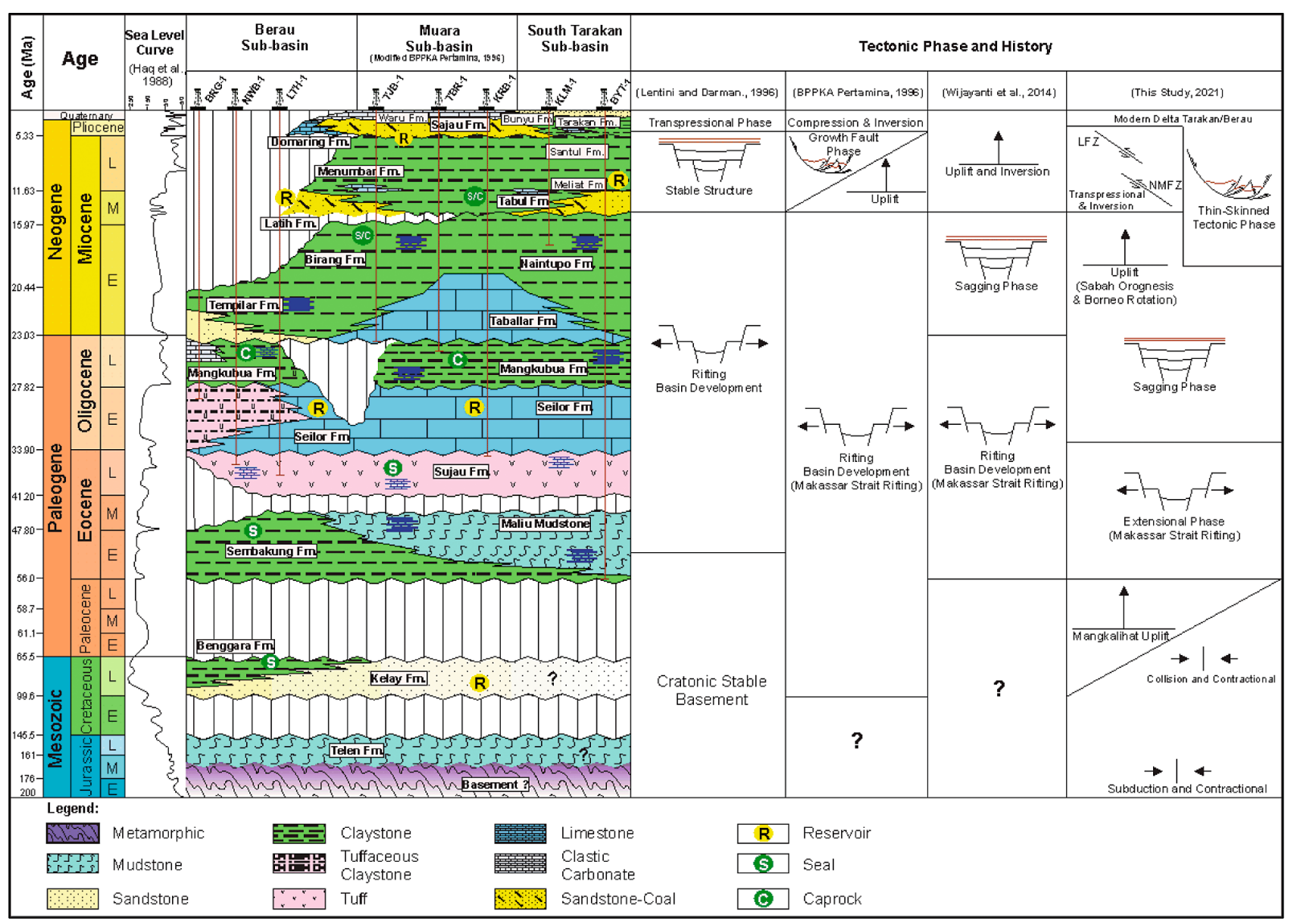

Figure 11: Comparison of tectonostratigraphy and tectonic evolution of the South Tarakan Basin.

post-extensional dominantlycarbonate deposits. According to Wilson and Evans (2002), the bioclastic and lithoclastic facies in eastern Mangkalihat (Muara Sub-basin) have primary porosity percentages of $5-35 \%$ and $5-15 \%$, respectively, while permeability is $10 \mathrm{~s}-100 \mathrm{~s} \mathrm{mD}$ and $10 \mathrm{~s}$ $\mathrm{mD}$. As a result, carbonate deposits with bioclastic facies have low to high reservoir potential, whereas those with lithoclastic facies have low to moderate reservoir potential. Early Miocene sequences are generally dominated by deep-marine transgression deposits. This sediment package is also fairly thick, so we assume that Early Miocene sediments have the potential of being seal rocks. Deltaic and fluvial facies developed during the Middle MiocenePliocene are interpreted as intraformational and have very high hydrocarbon potential.

Inverted and transpressional structures in the Berau Sub-basin form an anticline with a N-S pattern. The existence of this structural system is interpreted as a migration path and also controls the mechanism for the formation of hydrocarbon traps in the Berau Sub-basin. However, the presence of these structures is also a problem because the seal rock sediment packages are subjected to massive uplift and erosion. Meanwhile in the Muara Sub-basin, the absence of inversion and transpressional structures causes the migration path from Paleogene source rock to reach the reservoir to become a new and complicated problem.

\section{Conclusions}

- Based on the classification of strains that develop at each geological time interval, we divided the tectonic evolution of the Southern Great Tarakan Basin into four phases: (1) the Jurassic-Cretaceous contractional phase, (2) the Paleogene extensional phase, (3) the Early-Middle Neogene post extensional transitional phase, and (4) the contractional and thin-skinned tectonic phases in the Late Neogene-Quaternary;

- At least three phases of geometric change were caused by tectonic evolution, the first of which occurred during the Cretaceous period. A collision between the Partenoster and Sundaland microcontinents during the Cretaceous resulted in the formation of a continental shelf in the Southern Great Tarakan Basin. The second phase is the basin's opening during the Paleogene, as evidenced by groups of normal faults forming grabens and halfgrabens; regionally, the depocentre forms relatively following the normal fault line with the N-S pattern. 
The process of opening of this basin is closely related to rifting activities in the Makassar Strait during the Paleogene period. The final stage is associated with the development of shortening in the Late Neogene-Pliocene, which significantly impacts the Southern Great Tarakan Basin;

- The hydrocarbon potentials in Berau and Muara sub-basins are different from each other because the Muara Sub-basin is unaffected by inversion structures and transpressional systems. There are three petroleum plays in the Berau Sub-basin: (1) the Paleogene play with the Eocene sequence as source rock, clastic carbonate Early Oligocene as a reservoir and deep marine deposits from the Late Oligocene-Early Miocene as a seal rock; (2) the MiddleLate Miocene deltaic play and (3) the Pliocene fluvial-deltaic play;

- The presence of an inversion structure and a transpressional system generally controls the mechanism of trap formation, migration and accumulation. There are only two petroleum plays in the Muara Sub-basin: (1) the Paleogene play with sources, seals and reservoirs similar to those found in the Berau Sub-basin, and (2) the Neogene shallow-deep marine play;

- There are two types of traps in the Muara Sub-basin: the Paleogene play is dominated by a combination of structure and stratigraphic traps, while the Neogene play is characterised by only stratigraphic traps.

\section{Acknowledgment}

PT. Pertamina Hulu Energy supported this research financially and in terms of data availability, with master thesis contract number 933 /PHE436/2019-S8, and we thank PT. Pertamina Hulu Energy for the license to use the software. We would also like to thank the Research Center for Geotechnology, Indonesian Institute of Sciences (LIPI) Bandung for allowing the author to conduct laboratory analyses and everyone who helped with the field data collection process in northeast Borneo in 2019.

\section{References}

Ahmad, Z. and Samuel, L. (1984): Stratigraphy and depositional cycles in the N.E. Kalimantan Basin. Indonesian Petroleum Association Annual Convention and Exhibition, Jakarta, Indonesia, 109-120.

Amiruddin, (2000): Cordilleran and Caledonian types Cretaceous orogenic granitic rock belt: with granitic sample from west-east Kalimantan Indonesia. Journal of Geology and Mineral Resources, 10, 2-15.

Amiruddin, (2009): Cretaceous orogenic granite belts, Kalimantan, Indonesia. Journal of Geology and Mineral Resources, 19, 3, 153-221. http://dx.doi.org/10.33332/jgsm. geologi.v19i3.203.
Bachtiar, A., Pumama, Y. S., Suandhi, P. A., Krisyuniato, A., Rozali, M., Nugroho, D.H.H., and Suleiman, A. (2013): The Tertiary paleogeography of The Kutai Basin and its unexplored hydrocarbon plays. Indonesian Petroleum Association Annual Convention and Exhibition, Jakarta, Indonesia, pp. 1680-1716.

Balaguru, A. and Nichols, G. (2004): Tertiary stratigraphy and basin evolution, southern Sabah (Malaysian Borneo). Journal of Asian Earth Sciences, 23, 4, 537-554. https:// doi.org/10.1016/j.jseaes.2003.08.001

Balaguru, A. and Hall, R. (2009): Tectonic evolution and sedimentation of Sabah, North Borneo, Malaysia, AAPG International Conference and Exhibition, Cape Town, South Africa, 30084.

Chamov, N.P., Sokolov, S.Y., Garetskii, R.G. (2019): Structure and Evolution of Ancient and Modern Tectonic-Sedimentary Systems. Geotectonic. 53, 337-355. https://doi. org/10.1134/S0016852119030038

Cloke, I.R., Milsom, J. and Blundell, D.J.B. (1999): Implications of gravity data from East Kalimantan and the Makassar Straits: a solution to the origin of the Makassar Straits? Journal of Asian Earth Sciences, 17, 1-2, 61-78. https:// doi.org/10.1016/S0743-9547(98)00056-7

Doust, H. and Noble, R.A. (2008): Petroleum systems of Indonesia. Marine and Petroleum Geology, 25, 2, 103-129. https://doi.org/10.1016/j.marpetgeo.2007.05.007

Guntoro, A. (1999): The formation of the Makassar Strait and the separation between SE Kalimantan and SW Sulawesi. Journal of Asian Earth Sciences, 17, 1-2, 78-98. https:// doi.org/10.1016/S0743-9547(98)00037-3

Hall, R. (2002): Cenozoic geological and plate tectonic evolution of SE Asia and the SW Pacific: computer-based reconstructions, model and animations. Journal of Asian Earth Sciences, 20, 353-431. https://doi.org/10.1016/S13679120(01)00069-4

Hall, R. (2012): Late Jurassic-Cenozoic reconstruction of the Indonesian region and the Indian Ocean. Tectonophysics. 570-571, 1-41. https://doi.org/10.1016/j.tecto.2012.04.021

Hall, R. (2013): Contraction and extension in northern Borneo driven by subduction rollback. Journal of Asian Earth Sciences. 76, 399-411. https://doi.org/10.1016/j.jseaes.2013. 04.010

Hall, R. and Breitfeld, T.H. (2017): Nature and demise of the Proto-South China Sea. Bulletin of the Geological Society of Malaysia. 63, 61-76.

Haq, B.U., Hardenbol, J., and Vail, P.R. (1988): Mesozoic and Cenozoic chronostratigraphy and eustatic cycles. In: Wilgus, C.K. and Hastings, B.S.,Kendall, C.G.S.C., Posamentier, H.W., Ross, C.A. and Van Wagoner, J.C. (eds): SeaLevel Changes: An Integrated Approach. SEPM Special Publication 42, 71-108.

Hartono, U., (2012): Magmatism in Kalimantan. Centre for Geological Survey, Geological Agency, Ministry of Energy and Mineral Resources, Bandung, 199 p.

Hidayati, S., Amirudin, and Satrianas, D. (1995): Geological Map of Tarakan and Sebatik Quadrangle, Kalimantan. Scale 1:250.000. Research Centre Geological Survey, Bandung, Indonesia. 
Hidayati, S., Guritno, E., Argenton A., Ziza W. and Campana, I.D. (2007): Revisited structural framework of the Tarakan Sub-Basin Northeast Kalimantan. Indonesian Petroleum Association Annual Convention and Exhibition, Jakarta, Indonesia, pp. 109-137.

Hutchison, C.S., Bergman, S.C., Swauger, D.A., Graves, J.E. (2000). A Miocene collisional belt in north Borneo: uplift mechanism and isostatic adjustments quantified by thermochronology. Journal of the Geological Society London 157 (4): 783-793. https://doi.org/10.1144/jgs.157.4.783

Jamal, S.B., Supriatna, S., and Santosa, S. (1995): Geological Map of Muaralasan Quadrangle, Kalimatan. Scale 1:250.000. Research Centre Geological Survey, Bandung, Indonesia.

Koesoemadinata, R. P. (2020): An introduction into the geology of Indonesia. Ikatan Alumni Geologi Institut Teknologi Bandung, vol. 1, Bandung, 1037 p.

Krisnabudhi, A., Gunawan, A., Putra, Y.A., and Amal, A.N. (2020): New insight into Berau Sub-Basin northeast Borneo: basin evolution and tectonostratigraphy and their implication to new exploration play. Indonesian Petroleum Association Annual Convention and Exhibition, Jakarta, Indonesia, pp. 1168-1174.

Kupecz, J.S.I., Sayers, I., Tognini, P., Hilman, A., Tanos, C., and Ariyono, D. (2013): New insight into the tectonostratigraphic evolution of the South Makassar Basin. Indonesian Petroleum Association Annual Convention and Exhibition, Jakarta, Indonesia, pp. 1737-1777.

Lentini, M.R. and Darman, H. (1996): Aspects of the Neogene tectonic history and hydrocarbon geology of the Tarakan Basin. Indonesian Petroleum Association Annual Convention and Exhibition, Jakarta, Indonesia, pp. 241-251.

Macgregor, D.S. (1992): Relationship between seepage, tectonics and subsurface petroleum reserves. Marine and Petroleum Geology 10, 6. https://doi.org/10.1016/02648172(93)90063-X

Maryanto, S. (2012): Diagenesis and provenance of Lati sandstone in the Berau area, East Kalimantan Province, based on petrography data. Indonesian Journal on Geoscience, 7, 3, 145-156. https://doi.org/10.17014/ijog.v7i3.143

Maulin, H.B., Sapiie, B., and Gunawan, I. (2019): The Neogene deformation, unconformity surfaces and uplift features in delta tectonics, Tarakan Sub-Basin. Indonesian Petroleum Association Annual Convention and Exhibition, Jakarta, Indonesia, pp. 980-992.

Maulin, H.B., Sapiie, B. and Gunawan, I. (2021): Analisis sesar tumbuh pada sistem deformasi delta tersier di SubCekungan Tarakan, Kalimantan Utara (Analysis of growing fault on Tertier delta deformation system in Tarakan Basin, North Kalimantan). Bulletin of Geology, 5, 570579 (2021). (In Bahasa Indonesia). https://doi.org/10.5614/ bull.geol.2021.5.2.1.

Mitchum, R.M.Jr., Vail, P. and Thompson, S.,III. (1977): Seismic stratigraphy and global changes of sea-level, Part 2: The depositional sequence as a basis unit for stratigraphic analysis. AAPG Memoir 26, 53-62.

Morley, R.J., Morley, H.P. and Swiecicki, T. (2017): Constructing Neogene paleogeographical maps for the Sunda region. SEAPEX Exploration Conference, Singapore, 12-23.
Nawawi, A., Suseno, A., Heriyanto, N., Abdullah, M., Mertani, B., Kohar, A., Ponto, C.V., Darman, H., Ardana, W., Caughey, C.A., Bachtiar, A., Natanegara, D. (1996): Petroleum geology of Indonesian Basins: principles, methods, and applications. Pertamina BPPKA (Foreign Contractors Ventures Development Body), Jakarta.

Nur'aini, S., Hall, R. and Elders, C.F. (2005): Basement architecture and sedimentary fill of the north Makassar Strait Basin. Indonesian Petroleum Association Annual Convention and Exhibition, Jakarta, Indonesia, 14-29.

Pubellier, M. and Morley, C.K. (2014): The basins of Sundaland (SE Asia): evolution and boundary condition. Marine and Petroleum Geology, 58, 555-578. https://doi.org/ 10.1016/j.marpetgeo.2013.11.019.

Satyana, A., Nugroho, D., and Surantoko, I. (1999): Tectonic controls on the hydrocarbon habitats of the Barito, Kutai, and Tarakan Basins, Eastern Kalimantan, Indonesia: major dissimilarities in adjoining basins. Journal of Asian Earth Sciences, 17, 99-122. https://doi.org/10.1016/S07439547(98)00059-2.

Situmorang, R.I. and Burhan, G. (1995): Geological Map of Tanjung Redeb Quadrangle, Kalimatan. Scale 1:250.000. Research Centre Geological Survey, Bandung, Indonesia.

Soesilo, J., Schenk, V., Suparka, E. and Abdullah, C.I. (2015): The Mesozoic tectonic setting of SE Sundaland based on metamorphic evolution. Indonesian Petroleum Association Annual Convention and Exhibition, Jakarta, Indonesia, 1356-1368.

Supriatna, S. and Abidin, H.Z. (1995): Geological Map of Muarawahau Quadrangle, Kalimantan. Scale 1:250 000. Research Centre Geological Survey, Bandung, Indonesia.

Tiranda, H. and Hall, R. (2021): Structural and stratigraphic development of offshore NW Sulawesi, Indonesia. EarthArXiv, https://doi.org/10.31223/X5WC89

Tjia, H.D. and Ismail, M.I. (1994): Tectonic implications of well-bore breakouts in Malaysian basins. Bulletin of the Geological Society of Malaysia, 36, 175-186. https://doi. org/10.7186/bgsm36199416.

Tjia, H.D. (2012: The paleo-orientations of northwestern Borneo and adjacent South China Sea basins. Indonesian Journal on Geoscience, 7, 2, 67-76. https://doi.org/10.17014/ ijog.v7i2.136.

Wakita, K. (2000): Cretaceous accretionary-collision complexes in central Indonesia. Journal of Asian Earth Sciences, 18, 6, 739-749. https://doi.org/10.1016/S1367-9120 (00)00020-1

Wight, A.W.R., Hare, I.H. and Reynolds, J.R. (1993): Tarakan Basin, NE Kalimantan, Indonesia: a century of exploration and future potential. Bulletin of the Geological Society of Malaysia, 33, 263-288. https://doi.org/10.7186/bgsm3319 9319.

Wijayanti, H.D.K., Surjono, S.S. and Soedarmono (2014): The paleogeography of Berau Sub-Basin, NE Kalimantan. Proc 43rd Annual Convention Ikatan Ahli Geologi Indonesia IAGI, Jakarta, Indonesia, 6-12.

Wilson, M.E.J., and Moss, S.J. (1999): Cenozoic paleogeographic evolution of Sulawesi and Borneo. Paleogeography. Paleoclimatology, Paleoecology, 145, 303-337. https://doi.org/10.1016/S0031-0182(98)00127-8. 
Wilson, M.E.J., Chambers, J.L.C., Evans, M.J., Moss, S.J. and Nas, D.S. (1999): Cenozoic carbonate in Borneo: case studies from Northeast Kalimantan. Journal of Asian Earth Sciences, 17, 1-2, 183-201. https://doi.org/10.1016/S07439547(98)00045-2.
Wilson, M.E.J., and Evans, M.J. (2002): Sedimentology and diagenesis of Tertiary carbonates on the Mangkalihat Peninsula, Borneo: implications for subsurface reservoir quality. Marine and Petroleum Geology, 19, 7, 837-900. https:// doi.org/10.1016/S0264-8172(02)00085-5.

\section{SAŽETAK}

\section{Mezozoičko-kenozoička stratigrafska i tektonska evolucija južnoga dijela bazena Veliki Tarakan, sjeveroistočni Borneo, Indonezija}

Analizirane su stratigrafska i tektonska evolucija južnoga dijela bazena Veliki Tarakan tijekom mezozoičke i kenozoičke ere. Izučena je geometrija bazena te ugljikovodični potencijal povezivanjem površinskih i dubinskih podataka. Analizirani bazen dijeli se u tri podbazena: Berau, Muara i Južni Tarakan. U njima su istaložene stijene od jure do kvartara, koje se dijele u pet megasekvencija izdvojenih temeljem litoloških svojstava i tektonske evolucije. Također su tektonski događaji podijeljeni u 4 glavne faze: (1) kontrakcija tijekom jure i krede, (2) ekstenzija u paleogenu, (3) tonjenje u donjemu neogenu i (4) kontrakcija u gornjemu neogenu. Aktivnost rasjeda s naglašenim uzdužnim pomakom oblikovala je dva podbazena. Transpresijske strukture smjera pružanja sjeverozapad - jugoistok oblikovale su se tijekom kontrakcije (sažimanja prostora) utječući na većinu paleogenskih struktura koje su reaktivirane (rasjedi) i invertirane, dok se cijeli bazen izdignuo i erodirao. Posljedično, evolucija transpresijskih sustava prouzročila je podjelu cijeloga bazena Veliki Tarakan u pet podbazena od donjega miocena do pliocena. Nadalje, izdvojeno je pet horizonata s ugljikovodičnim potencijalom u Južnome Velikom Tarakanu, i to tri stratigrafska horizonta u podbazenu Berau i dva u Muari. Gornjoneogenske strukture opisane u podbazenu Berau obuhvatile su migraciju, nakupljanje ugljikovodika i stvaranje strukturnih zamki, dok su u Muari zamke stratigrafske.

Ključne riječi:

jura - kvartar, stratigrafija, tektonika, ugljikovodični potencijal, sjeveroistočni Borneo

\section{Author's contribution}

Alfathony Krisnabudhi (M.Sc., structural geologist, structural geology and tectonics) as the main contributor, performed fieldwork activities and provided seismic-well interpretation, tectonic reconstruction, and petroleum system analyses. Benyamin Sapiie (Professor, principal structural geologist, structural geology and geomechanics) as an advisor, guided to build detailed structural analysis and regional structure, as well as a regional tectonic map in the Berau Sub-basin. Agus Men Riyanto (B.Sc., senior researcher, geology, research administrator) as the main contributor, provided petrography and paleontology laboratory analyses and administered the research. Adi Gunawan (M.Sc., Sr. exploration geologist, exploration geology and petrophysics) performed geological mapping and provided subsurface data and petroleum system analyses as well as founded fieldwork activity in Berau, Mangkalihat, and Bunyu Northeast Borneo, Indonesia. Febriana Fiona Rizky (B.Sc., Jr. geologist, stratigraphy) provided the result of sequence stratigraphy based on well interpretation. 